\title{
Economic benefits of tourism: Cultural identity and tourism destinations in the Czech Republic
}

\author{
Irena Tyslová \\ Metropolitan University Prague, Prague, Czech Republic \\ e-mail: irena.tyslova@mup.cz \\ Josef Abrhám \\ Metropolitan University Prague, Prague, Czech Republic \\ e-mail: josef.abrham@mup.cz \\ Zuzana Horváthová \\ Metropolitan University Prague, Prague, Czech Republic \\ e-mail: zuzana.horvathova@mup.cz \\ Filip Rubáček \\ Metropolitan University Prague, Prague, Czech Republic \\ e-mail: filip.rubacek@mup.cz
}

\begin{abstract}
Citation: Tyslová, I., Abrhám, J., Horváthová, Z., Rubáček, F. (2020). Economic benefits of tourism: Cultural identity and tourism destinations in the Czech Republic. Terra Economicus, 18(2), 139-154. DOI: 10.18522/2073-6606-2020-18-2-139-154

Our paper focuses on the economic benefit of tourism by evaluating the compliance between the destination identity and the identity of residents on the example of a selected tourist area. One can see that the identity of the destination is reflected in the product offer and can be found in media messages. The identity of residents was ascertained by a survey. Our research is divided into three main parts. The first part of the research included an analysis of the destination offer within the website and Facebook page. The second part of the research is focused on the analysis of the tourism destination in the media. These two methods are used to analyse the identity of the destination. A group interview was chosen to analyse the identity of residents. The third research was carried out using the focus group method. Our methodical procedure is tested on a case study of a selected destination Toulava (a Czech tourist area located on the border of South and Central Bohemia), however it is designed to be universally usable within tourism destinations. Our results confirmed that the model-defined path for memory destination selection by destination management and its use in the business offer to create product cores works. The high degree of product authenticity has been confirmed. The applied research methodology enabled to obtain relevant outputs. It is not common in general practice that the identity of the destination is examined together with the identity of its residents. The three methods used in this article are less demanding in terms of capacity and cost than the quota sample research. Research can thus be carried out in destinations repeatedly and follow time series.
\end{abstract}

(ㄱ) И. Тыслова, Й. Абрхам, 3. Хорватова, Ф. Рубачек, 2020 
Keywords: tourism economics; destination management; sustainability; cultural identity

Acknowledgements: This paper is the result of Metropolitan University Prague research project no. 74-03 «Public administration, legal disciplines and industrial property» (2020) based on a grant from the Institutional Fund for the Long-term Strategic Development of Research Organisations.

JEL codes: $D 11, Q 2, L 83, M 10$

\title{
Экономические выгоды туризма: культурная идентичность и туристические направления в Чешской Республике
}

\author{
Ирена Тыслова \\ Метропольный Университет Праги, г. Прага, Чешская Республика \\ e-mail: irena.tyslova@mup.cz \\ Йосеф Абрхам \\ Метропольный Университет Праги, г. Прага, Чешская Республика \\ e-mail: josef.abrham@mup.cz \\ Зузана Хорватова \\ Метропольный Университет Праги, г. Прага, Чешская Республика, \\ e-mail: zuzana.horvathova@mup.cz \\ Филип Рубачек \\ Метропольный Университет Праги, г. Прага, Чешская Республика \\ e-mail: filip.rubacek@mup.cz
}

Цитирование: Тыслова, И., Абрхам, Й., Хорватова, 3., Рубачек, Ф. (2020). Экономические выгоды туризма: культурная идентичность и туристические направления в Чешской Республике // Terra Economicus, 18(2), 139-154. D0I: 10.18522/2073-66062020-18-2-139-154

Наша статья описывает экономическую выгоду туризма путем оценки соответствия между идентичностью места назначения и идентичностью жителей на примере выбранной туристической области. Известно, что идентичность пункта назначения отражена в предложении продукта, а также в средствах массовой информации. Идентичность жителей была определена посредством опроса. Наше исследование состоит из трех основных частей. Первая часть включает анализ предложения места назначения на веб-сайтах и в сети Facebook. Вторая часть исследования посвящена анализу туристических направлений в СМИ. Два обозначенных метода используются для анализа идентичности пункта назначения. Для анализа идентичности жителей был выбран метод группового интервью. Третья часть исследования была прове- 
дена с использованием метода фокус-групп. Наша исследовательская процедура опробована на примере Тулавы (официальная туристическая зона, расположенная на границе Южной и Центральной Богемии); однако данная процедура подходит для анализа любых туристических мест. Результаты исследования подтвердили эффективность способа выбора места назначения, основанного на использовании модели управления определением туристического направления, а также его использование в бизнес-предложениях для создания основного туристического продукта. Также была подтверждена высокая степень подлинности продукта. Три метода, использованные в данном исследовании, менее требовательны с точки зрения охвата и затрат, чем в случае квотной выборки. Таким образом, подобные исследования могут проводиться по разным туристическим направлениям многократно и с использованием временных рядов.

Ключевые слова: экономика туризма; туристический менеджмент; устойчивое развитие; культурная идентичность

Благодарность: Данная работа подготовлена в рамках исследовательского проекта № 74-03 «Государственное управление, правовые дисциплины и промышленная собственность» (2020), реализованного Метропольным университетом в Праге, в рамках гранта, предоставленного Институциональным фондом долгосрочного стратегического развития исследовательских организаций.

\section{Introduction}

There is no doubt about the economic benefits of tourism (Van der Schyff et al., 2019; Peeters et al., 2019). It builds on the development strategies of organizations and regions. The sought-after destination shows high income, employment and quality services for tourists and residents. High attendance also brings significant changes in the form of the destination. Tourism infrastructure is expanding, transport is strengthened, and several products are being created (Abrhám, Wang, 2017; or Shevyakova et al., 2019). Tourism preferences in the destination can lead to the residents leaving the site completely, coming to work there, and the normal life of the destination disappears (Oh et al., 2007; Chiabai et al., 2014). It was the changes in the local culture that led to the increased interest of sociologists and anthropologists in sustainability of the tourist destination identity (Xue et al., 2017). The success of the destination in relation to tourists is relatively logically assessed by the number of arrivals, the length of stay, the amount of expenditures per person, etc. Sustainable development of the destination from a social point of view is only possible if the identity of the destination (promoted in marketing communication) and the identity of residents is reached (Zhang, Xiao, 2014; Maitah et al., 2016; Radovic et al., 2017; Eslami et al., 2018; or Pavolová et al., 2019). There is a consensus in the theoretical resources available and in the research that the identity of the destination and residents is necessary. However, destination management theories are confined to claims of need for compliance, without describing how to define and examine it (Černevičiūtè, Strazdas, 2018). The aim of this article is to evaluate the compliance between destination identity and identity of residents on the example of a selected tourist area. The methodological procedure of the solution is since the identity of the destination is reflected in the product offer. It can be found in media messages. The identity of residents was ascertained by a survey. Based on the results of testing, a generally applicable methodical procedure for the evaluation of relations in the destination will be proposed. They focus on two main 
items - identity of destination and identity of residents. The compliance of the offer with the declared destination strategy and especially the identity with the residents' identity is examined. The methodical procedure is tested on a case study of a selected destination Toulava. However, it is designed to be universally usable within tourism destinations. The research is divided into three main parts. The first part of the research included an analysis of the destination offer within the website and Facebook page. The second part of the research focused on the analysis of the Toulava destination in the media. These two methods are used to analyse the identity of the destination. A group interview was chosen to analyse the identity of residents. The third research was carried out using the Focus group method. The group interviews were focused on obtaining information about the identity of residents (residents of the two largest settlements of the selected destination of Toulava - Tábor and Sedlčany). The sample of respondents was selected with regard to the specific focus of the research. The sample was not random. As the first recruiting criterion, the selection of members of the focus group was meeting at least 7 years spent in the destination. The second criterion was that they must not have a job or any other interest in tourism. Focus groups within the Toulava destination included a sample of 11 persons involved in Sedlčany and 12 persons in Tábor. The focus group method was used for several reasons.

Our method provides reliable quality data. Moreover, it is also a cost-effective method. It can also be recommended for repeated research in tourism destinations. Destinations usually do not have sufficient financial resources to carry out an extensive quantitative survey.

This paper is structured as follows: Section 2 presents the economic and cultural identity contexts. Section 3 offers a comprehensive literature review. Section 4 offers the methodological framework. Section 5 focuses on the identity interaction with destination management. Finally, Section 6 provides conclusions and implications.

\section{Economic and cultural identity contexts}

The concept of identity has been known since the Antiquity period and has been solved for a long time in more professional discourses (Rýsová, Dobrýk, 2013). Individual identity includes values that an individual believes in and which gives him a meaning in life (Jandourek, 2001). Sociology defines collective identity in addition to individual identity. This is based on the following categories: territory, language, ethnicity and important pillars (places, personalities, buildings). Based on these, a number of types of collective identities can be defined. The most important types of identities for defining the problem under investigation in this article are listed below.

The topic of collective identity can be found in sociology. It perceives identity as a deep sense of identity, based on experiencing its own community. It also encompasses the values that an individual believes in and bases on the meaning of his or her life. The term nation has existed since the ancient Middle Ages and has continually moved into modern languages. The meaning of the term varies according to time and place of use. In England, the concept of nation was intricately linked to the concept of state. While in Germany the concept of nation was more related to common customs, language, and origin. But the meaning of the terms has changed over the years (Hippo, 2004). Nations are defined mainly by culture, political existence, and psychological dimension. The belonging to a given nation is given objectively and subjectively. Objective features include culture, language, political ties, and ties to territory. Subjectively, a nation is differentiated through its own affiliation to the nation and desires to be identified with that nation. The mutual recognition that persons belong to a common nation is important (Gellner, 1993). Culturally, nations are mostly made up of a common language, history, traditions, and religion. Political existence is most often given by collective identification with a clearly defined political space. The psychological existence is based on the subjective awareness of individuals about their nationality. A strong national consciousness is 
called patriotism (Linhart et al., 1996). The concept of national identity includes two basic concepts - nation and identity. Identity can be defined as a deep sense of self-identity based on experiencing one's own community. National identity can be understood as a collective social identity, which is projected as a positive relationship of an individual to one's own nation and country (Jandourek, 2001). Czech national identity is connected mainly with language, culture and traditions, the element of religiosity is weak. Czechs feel more belonging to people of a similar job, family, people of the same sex and age than those of their nation. In the Czech Republic there is a relatively strong identification with the state and its territorial units, such as a municipality, city or region. Culture in the present means confirming a specific identity (national, ethnic, regional). From the logic of cultural nationalism, culture and history are the most valuable assets of society. Cultural diversity is one of the most distinctive features of human society (Horáková, 2007). The coexistence of different cultures is one of the main themes of contemporary anthropology. Contemporary global civilization is undergoing extensive cultural, ethnic, social, economic, and religious transformations. The period of domination of civilization based exclusively on Western values ends. At the same time, a new civilization, in the true sense of the world, is born. A civilization that can be called post-industrial, post-ideological, post-modern, multicultural, and multi-racial (Budil, 2013). Huntington (2001) predicted that the main feature of the emerging world would be its division into eight major civilization circles (Western, Confucian, Japanese, Islamic, Hindu, Slavic-Orthodox, Latin American, and African). There will be a competitive struggle between these areas, which will be interrupted by the conclusion of special-purpose alliances. He questioned the traditional strategies of Western civilization in the post-colonial era. The promotion of the universalism of human couples acts as a manifestation of arrogance. Tolerant multiculturalism, in turn, weakens Western society in a conflict with the Islamic world (Huntington, 2001). Anthropology must tackle major challenges that address the issues of different ethnicities, subcultures or populations, international migration, multiculturalism, poverty, underdevelopment, the portability of democratic traditions and other topics. The solution to these disproportions is an expression of the maturity of today's civilization (Budil, 2013).

Regional identity is defined as the relationship between man and place. It is usually a place where a person has long-lived or lived. Regional identity is a "theoretical category" which as such is not usually given much importance for everyday life (Paasi, 1986: 131). According to Paasi, regional identity is composed of two basic elements. The first is the regional identity of the population, which consists of identifying residents with the community and the region. The second cornerstone is the identity of the region. Paasi (1986) divides it into objective (scientific) and subjective (image of the region). Objective contains objectively verifiable data (mostly statistical data). Subjective identity (image of the region) is formed by perception of the region from the viewpoint of the population and perception of the region from the outside viewpoint (Paasi, 1986; or Naglova et al., 2017).

In order to understand identity in the context of tourism, it is necessary to first define the destination of tourism and the destination management system. Šauer (2015) defines a travel destination as a geographically determined travel destination. A destination is represented by a bundle of different services concentrated in a location or area. Tourism destination is an area that has unique characteristics in terms of tourism development conditions. It can be defined at continental, national, regional or local level. The destination is therefore a designated geographical area in terms of the broadest to the local place.

The term destination management is an advanced form of management that guarantees the competitiveness and quality of service in a unique environment. It is a set of approaches, opinions, recommendations, and methods that managers use to manage specific activities to achieve a set of goals for a particular destination (Vasylchak, Halachenko, 2016; Koilo et al., 2020). In this respect, tourism actors need to be linked to joint leadership, coordination of activities and mutual communication. Tourism actors in the destina- 
tion include managing, business, public sector and non-profit organizations. Due to the emphasis on the communication part of the management process, networking is a suitable tool for destination management. One of the main goals of destination management is the effort to influence the quantity, composition, temporal and spatial distribution of demand in the destination, provided the profit and satisfaction of all parties involved. Nowadays it is clear that the spontaneous development of tourism can bring negative impacts on the economic, social and ecological area of the destination. Examples are oversized resorts in the Mediterranean, in mountainous areas or even in city centres, which have been transformed into fairground attractions without everyday life, demonstrating all the negative effects of poorly managed or unmanaged destinations: ecological congestion, McDonaldization of cultural traditions, or breakdown of social ties or religious beliefs (see Richards, 2007; Strielkowski, Čábelková, 2015; or Lisin et al., 2018).

Identity is not a static phenomenon. It develops over time and can be influenced as indicated above (Paasi, 1986). This research is also based on defining the identity of the tourist destination, which also includes the requirement for compliance with the identity of residents in space and time.

The identity of a tourist destination can be defined as a kind of collective identity where a group of residents living in a particular tourist destination identifies not only its tradition and cultural-historical specifics, but also the basic philosophy, objectives, means and procedure of local destination management (Zelenka, Paskova, 2012). The concept of destination identity is reflected in the main product of the destination. This product is defined from the point of view of destination management as a multifunctional offer characterized by the main theme. The main topic is to be communicated so that it can be perceived by visitors and residents throughout their stay in the destination (Palatková, 2011). According to another definition, destinations are competing entities that fulfil a number of functions (marketing, offering, representation of different interest groups and planning function) whose common goal is to sell (Jakubikova, 2009).

In the tourist destination, it is advisable to examine and assess the identity of residents and their compliance with the identity of the destination. Destination identity is communicated by destination management for business purposes. The establishment and functioning of a region / destination usually has historically given reasons and is a complex process depending equally on the agreement of initiators, residents and official institutions. Regions can support the activity of the population while being created and influenced by the activities.

Destination identity can be a key identifier to support destination marketing. Identity can be part of the marketing mix of both the product and the people element. In any case, it should be part of the primary analysis and subsequent destination strategies and plans. Palatková (2011) mentions local cultural identity and its preservation and development as a precondition for well-managed sustainability of the destination and its socio-cultural pillar. However, it also mentions the problematic nature of the objective assessment of this category. It develops a comprehensive view of destination management, where respect for local identity is always a key part of the destination's mission. Destination identity intersects all three layers of the destination product. It is possible to identify with a specific attraction, a sub-product and a comprehensive product of a destination. Peter Burns looks at the destination's identity as an element that meets the above business requirements. At the same time, however, it is very often at risk, especially in connection with oversized tourism. The loss of cultural identity leads to a deterioration in the business performance of the destination. Loss of authenticity is most often mentioned (Burns, 1999; Burns, Noveli, 2006).

Sustainable development ensures consistency between the identity of destinations and the identity of residents. The Tourism Glossary also refers to residents as the host community, for example the locals of the tourist destination who officially or acciden- 
tally share their land, cultural, sports and other facilities, roads, public spaces, culture, social contacts, etc. with their visitors, culture, behaviour, habits, lifestyles and lifestyles can be strongly influenced by visitors and by the development of tourism infrastructure. They should be involved in all decisions in the planning and implementation of tourism activities and included in the planned development of the tourism destination as an active element, influenced and influenced by tourism (Zelenka, Pásková, 2012: 108). Participation of residents and consideration of their needs in the development of local tourism are the basic principles of sustainability of tourism in the destination. And that the preference for meeting the needs of tourists over the saturation of resident needs usually results in one or more of the following negative phenomena: host community aversion to visitors, falling into a tourist trap, the emergence of a tourist ghetto or a reduction in socio-diversity. This greatly limits memory space. Memory is a phenomenon that is crucial in destinations and ceases to exist without residents and, in the form of so-called memory locations, enters the products of the destination (Zelenka, Pásková, 2012: 253). Tourism products representing the attractiveness of the destination can be considered as pillars of memory that are repeated and emphasized both by the system of socialization and by the interest of tourists.

\section{Literature review}

There have been relatively few researches on this topic. Relatively extensive anthropological research by Czech authors (Horáková, Fialová, 2014) has repeatedly followed a specific type of international tourism. Together with a team of researchers, the authors conducted a long-term (six-year) focused anthropological research in the villages of Lipno and Vltavou, Stupná (Vidochov), Čistá (Černý důl) and Stárkov. The municipalities are connected by the realized concept of so-called Dutch villages. Within the municipalities, Dutch investors have built tourist centres, which are regularly visited by visitors mainly from the Netherlands, but also from other countries. The aim of the research was to explain the processes of post-socialist transformation (transformation of rural space into a space of so-called modern rurality) and development strategies about the role of tourism. The research also examined how contemporary forms of international tourism have an impact on local social organization and social relations. Despite the interesting results, the research of the so-called Dutch villages is not generally applicable. In any case, however, he described the influence of tourism on the emergence of dual society (Horáková, Fialová, 2014). This research shows that tourism, despite the region's economic prosperity, can upset the balance of the socio-cultural pillar of sustainability. Research and its results demonstrate the need to strike a balance between each of the three pillars of sustainability in tourism. At the same time, the research confirms the need to address local identity not only as a capital enabling commercialization, but also as a soft characteristic of the input indicator of a development project.

Research into the perception of residents' identity in tourist destinations is also not common in the world. One of the few international studies is the research by Huimin and Ryan, who conducted a comparative study of business perception and perception of residents in a developing destination of the Three Lakes Region in north central Beijing. Surveys were conducted in 2006 and 2008 (40 business managers and 400/352 residents). Entrepreneurs rated tourism positively, residents were ambiguous. The authors showed a positive development of the relationship of residents to tourism over time. This research demonstrates the need to re-examine identity (Huimin, Ryan, 2011).

The issue of destination identity and residency identity research was directly investigated by the attitudes of destination managers in the Czech Republic. Research topics included identity, representation and animation in the tourist destination. The research showed a discrepancy between the generally declared need for compliance and the real state. All destination company managers confirmed the match between destination iden- 
tity and residency identity. However, from the other data provided, actual compliance was not confirmed (Herget et al., 2015).

Interesting is also the imbalance of research into the sustainability of tourism, where most of the outputs focus on the ecological and economic pillar of sustainability, while the socio-cultural pillar is usually only briefly described with the remark that its assessment is complicated and subjective. Socio-cultural aspects are often reduced to the theory of corporate culture (in which the destination is perceived as a company) and confined to the need to avoid conflicts. Of course, this is also important for the destination, the negative social phenomena resulting from a long-term disagreement between the destination identity and the identity of residents is the host community's aversion, the effect of a tourist trap, dual society and a positive ghetto (Čajka, Abrham, 2019).

In the theoretical resources available and the research carried out, it is agreed that consistency of destination and residency identity is essential for the sustainability of tourism (Svobodová, 2016). However, destination management theories are confined to claims of need for compliance, without describing how to define and examine it. The authors of this article try to propose a methodical procedure for evaluation of relations in the destination. They focus on two main items - destination and residents. The compliance of the offer with the declared destination strategy and especially the identity with the residents' identity is examined. The methodical procedure is tested on a case study of a selected destination. However, it is designed to be universally usable within tourism destinations.

\section{Methodological framework}

The study of the interaction between identity and destination management was conducted on a case study of the Toulava destination. Destination company Toulava, o.p.s. is an official tourist area on the border of South and Central Bohemia. From the perspective of destination management, the destination of Toulava is internally divided into seven micro-regions: Sedlčansko, Krajina Srdce, Táborsko, Central Povltaví, Lužnice, Soběslavsko and Pod Horou. The center of the destination Toulava is the historical town Tábor. For the purposes of this research, the distribution according to tourist maps was used: Surroundings of Lužnice (Táborsko, Soběslavsko), Hory Toulavy (Czech Siberia - Jistebnice, Mladovožicko), Between Vltava and Smutná (Milevsko, Bechyně), From Vltava to Český Merán (Sedlčansko, Prčicko). Destination company Toulava, o.p.s. was founded in 2013. Destination company was initiated by municipalities and entrepreneurs. In 2016 it was certified as a tourist destination of the South Bohemian Region. Toulava covers an area of over $2200 \mathrm{~km}^{2}$ and includes 155 municipalities with 144,000 inhabitants.

The research methodology is based on several methods covered by sequential triangulation. In the sequential triangulation method, the results of one research are used for the next research. However, the conclusions are formulated from all the researches. Following the objectives of the article and analysis of theoretical resources, the following research methods were chosen:

1. Destination offer analysis.

2. Analysis of media content.

3. Method of group interview with residents.

Destination offer analysis was chosen because the entire destination management is fundamentally shifted to the level of marketing, for which the creation of the offer is crucial. In theoretical sources, the media are described as the most powerful communication tool for both product offerings and local collective memories. These two methods evaluate destination identity.

The research would therefore be divided into three parts. The first part of the research included an analysis of the destination offer. For getting a complete overview of the communication activity focused on the destination offer, there were two main tools used for 
the presentation of the offer. The official websites of the destination, website Toulava.cz and Facebook page were analysed as the main channels for the presentation of the offer and products. The website was chosen based on the finding that all communication tools are created directly for or located on the site. The only exception is the personal communication of the representatives of destination management at fairs or local events in which the destination participates. To evaluate the offer of the destination Toulava, the information from the website toulava.cz was used, namely: categories (destination, trip, and activity), area (Tábor, Soběslav; Mladá Vožice, Jistebnice; Bechyně, Milevsko; Sedlčany), types of activities (recreational, historical, traditionally cultural, artistic, agricultural, gastronomic, industrial, ecclesiastical, and environmental).

The following periods were chosen for the analysis of the Toulava.cz facebook page: $1 / 5 / 2018-31 / 5 / 2018$ (spring, low season, out of holidays, pleasant spring weather); $1 / 7 / 2018$ - 31/7/2018 (summer season, school holidays, peak period); 1/10/2018 31/10/2018 (autumn, post-holiday off season); 1/1/2019 - 31/1/2019 (winter season, good conditions for skiers, outside spring school holidays).

The second part of the research included an analysis of the Toulava destination in the media. Anopress IT full text database with two selection parameters was chosen as a source of information about the presentation of the Toulava destination in the media. The media was researched for 2018. The inclusion of a closed one-year cycle made it possible to monitor seasonal effects. The following categories were evaluated in the media analysis:

- media type (TV, radio, press, magazine, regional TV / radio, regional press / web); Headline or headline placement (yes / no),

- journalistic unit (short article, medium article, interview, report),

- roaming as a topic (main / minor / marginal); event as topic (main / minor / not event),

- topic from TOP catalog (yes / no),

- the mentioned area of Toulava according to maps (1 Táborsko, Soběslavsko, 2 Milevsko, Bechyňsko, 3 Sedlčansko, Prčicko, 4 Czech Siberia (Jistebnice, Mladovožicko),

- thematic focus on attractiveness (1-Recreational, 2-Historical, 3-Traditional Cultural, 4-Artistic, 5-Agricultural, 6-Gastronomic, 7-Industrial, 8-Church, 9-Environmental),

- tonality (positive / neutral / negative),

- part of the campaign (yes / no).

Definition of the system of attractions was crucial for the investigation of the destination identity. For the purposes of media analysis, website, and Facebook page. The research pursues the following categories of attractions: ethnic, traditionally cultural, historical, environmental, recreational, commercial, agricultural, cultural, gastronomic, industrial, ecclesiastical, industrial and church (Gouldner, Richie, 2014). Each core of the product in the destination can be assigned a specific type of attraction, or several different attractions at the same time.

The third part of the research serves to obtain information about the local group identity of the inhabitants of the two largest settlements of the destination. Focus group method will be used.

The Focus group method was used for several reasons. This method provides quality data. Moreover, it is a cost-effective method. It can also be recommended for repeated research in tourism destinations. Destinations usually do not have sufficient financial resources to carry out an extensive quantitative survey. The Focus group method, also called the group interview method, is widely used to assess the impact of marketing communication. It is generally defined as a structured discussion with a small group of people, managed by a facilitator or a team of moderators. The aim was to identify a group interaction that could not be achieved through individual questioning.

The group interviews were focused on obtaining information about the identity of residents (residents of the two largest settlements of the selected destination of Toulav). 
The sample of respondents was selected regarding the specific focus of the research. The sample was not random. As the first recruiting criterion, the selection of members of the focus group was meeting at least 7 years spent in the destination. The second criterion was that they must not have a job or any other interest in tourism. Given the recommended effectiveness of group interviews, the aim was to obtain a sample of 7-12 participants. Focus groups within the Tourlava destination included a sample of 11 persons ( 5 women and 6 men) involved in Sedlčany, 12 persons ( 7 women and 5 men) in Tábor. The age range in Sedlčany was 31 to 71 years, the shortest time a respondent lives in a locality is 26 years. Six people have lived in Sedlčany all their lives. There were 5 university students, 5 high school students and one person with apprenticeship. In Tábor, the age range was 19 to 78, and only two respondents were not resident in the Tábor region all their life, but at least 32 years. The group consisted of 4 undergraduates, 6 high school students and 2 people with an apprenticeship certificate.

In group interviews, group interaction is a great advantage. Therefore, the researcher allowed interaction. Participants were asked about their comments on what another respondent said. The interviews were organized by two facilitators. Facilitators acted impartially towards the respondents, maintaining conversation within the topic.

The questions for the group interview were structured into three basic themes: identity (territory, people, pride and emotion), tourism in the region and destination management intentions. The structure of questions for group interviews was follows:

1. Identity:

- Where do you feel at home?

- Where do you still feel "like" at home?

- What places, emotions, situations will give you a feeling of well-being, what do you turn to when you want to relax or make yourself happy?

- What is typical for people in the region?

- Are their speech, tradition different?

- What personality will you think of in relation to your region / city?

- Where do you take a visit in and out of the city?

- What are you proud of?

- What do you think is typical of your region?

- In your experience, what do visitors associate with your region?

- Who introduced you to places you love, which you are proud of?

- Do you like it here?

- What is your heart matter?

2. Tourism in the region:

- Do tourists go to your region/city? How do you perceive them?

- What do you consider to be the best souvenir from your city/region? What do you give to visitors?

3. Destination management objectives:

- How do you perceive the Toulava destination company? What do you know about her, her intentions?

- Do you think there should be more tourists?

- How would you make people stay longer and come back?

All three methods of research are qualitative. The research data obtained is coded using the attraction sign system used to ensure comparability of results. The coding system is based on the division of attractions into 12 categories: ethnic, traditional cultural, historical, environmental, recreational, commercial, agricultural, cultural, gastronomical, industrial and ecclesiastical (Goeldner, Richie, 2014). In terms of analysing the destination offers on the website, media analysis and focus group research, expressions are always detected, which are then translated into one or more types from a set of 12 attraction categories. The methodological approach is recommended in general for carrying out re- 
search into identity interaction and destination management. Research data results can be compared to each other, track trends, and thus eliminate the potential risk of negative impacts resulting from growing identity mismatches. Results and mutual iteration of method results is evaluated in the next and final part of the study.

\section{Identity interaction with destination management}

\section{Destination offer analysis}

From the point of view of individual areas and their share in web content, it is clear that the offer benefits and focuses on the Tábor region ( $41 \%$ of the total offer), to a lesser extent on the Sedlčany and Bechyně-Milevsko regions (both approximately $25 \%$ ). Bid is only $10 \%$. The reason for the superiority of the Tábor region is obvious - the concentration of historical and artistic attractions, cultural opportunities and pleasant nature is historically given.

In terms of representation of individual types of attractions in the offer (connotation of the product offer), it turns out that besides recreational attractiveness, the main drivers are historical and artistic (represented by the present architecture). For some other types of attractions, the data reveal certain local variations, such as the largest proportion of agricultural attractiveness in the Sedlčany region (given by the number of farms and agro tourism), the interesting highest proportion of church-type attractions in Bechyně. Another important attraction is nature; in the framework of research, environmental attractiveness is used only in the context of an important natural habitat, habitat or reserve. But in the offer of the Toulava website, all items of the trip type having some natural interest were mentioned there.

The structure of the menu, if one can call it a Facebook discussion (FB), is entirely subordinate to the design and functioning of Facebook. The offered destinations, trips are given without details, in the vast majority of posts is inserted a link to the official website of Toulava. As in the case of the site, the surveyed (defined) area structure was the same. Generally, one can say that the offer in both examined environments (websites and social networks) seems to be the same on the first impression and is not in conflict with the main motto of the destination (home). In greater detail, there are slight differences between the website and the FB page. Perhaps the most fundamental differences are in the lower focus of FB inputs on goals and events with artistic appeal. There is also a markedly higher proportion of FB contributions focusing on natural beauty (environmental attractiveness, primarily on their emotional level).

The predominant attraction within the website and FB pages is the recreational attraction, which is precisely the fact that we can relax here as well as at home. There is nothing built on adrenaline and high physical demands in any part of the offer. In all the results, the historical attractiveness, associated with small and larger, less or more well-preserved historical buildings, was highly placed. These represent historical roots, which also each has the right home. Environmental attractiveness is less represented in the results, mainly because of the coding condition (only exceptional sites are recorded for environmental attractiveness), but it is often present. Artistic attractiveness is also significant. All in all, at the level of connotations, the offer of the Toulava destination corresponds entirely to the spirit of the motto, which describes the destination as a heart and home landscape.

\section{Analysis of media content}

In the extended period 133 media outputs related to the destination Toulava were found. Based on the research results, it can be stated that the intensity of Toulava's media presentation has been steadily decreasing since 2016. A significant decrease was recorded in 2018. This year the media presentation was also low on a regional scale. The media presentation of 
Toulava in the region is one of the basic prerequisites, respectively. Effective opportunities to create a positive perception of Toulava's activities and strategy by local residents.

Regarding the structure of media outputs, positive is the finding that $67 \%$ of the output is in regional press/web/radio. At regional level, awareness of Toulava, its existence, content, strategy, etc., can better reach one of the important components of the life mechanism of a living tourist destination - residents. From the point of view of the location of Toulava in the headlines of the media outputs, there is a decrease. Since the end of 2017, Toulava has appeared in headlines only once every 15 months. In the period 2015-2017, Toulava was presented in the headlines in the order of one third of the outputs. In the investigated media outputs, Toulava appeared in more than $80 \%$ as secondary or even marginal information. The topic of the output was general (tourism, travel). Of the monitored forms of media output, the form of the report clearly dominates. Other types of media output are relatively balanced, but significantly less. However, report-type outputs are often brief, only a few-line messages. Most often they are trailers for a certain event or novelty. These outputs are of limited value for the uninformed recipient. There will be no major interaction based on the short report. On the other hand, for longer articles or interviews, it is expected that if the reader addresses the topic as such, he or she learns relevant information and is more likely to take a position on the topic. Most of the interviews analysed were not direct interviews with a representative of the Toulava destination company. The interviews were mostly conducted with the creators or operators of the sub-product or with tourism experts who are not directly involved in the activities of the destination company. In cases where a specific attraction was mentioned in the media output, traditionally cultural (44\%) and recreational (22\%) were often presented.

From the point of view of tourism development, it is advisable to watch the media picture of events. In the media outputs, references to events (events organized in the destination) occur practically only until mid-2017, and only sporadically at the end of 2018. The Toulava.cz website lists at least 31 festival-type items that clearly meet the parameters for the event. Toulava is not the organizer in these cases, it states the events as part of the "offer". In the media news, the main topic is not Toulava, but the event and its course, details, or invitation.

Overall, the outputs sound slightly positive (half of the outputs are positive, half neutral). During the monitored 4 years, there were only 2 negative outputs. One reports on the absence of Toulava at the fair, the other claims tourist maps prepared by Toulava. Given the focus of the outputs, such a tonality can be expected. The trend of positive media presentation is increasing during the period under review. From the point of view of the tourism destination, it can be considered important that the poor experience of visitors with the quality of the offer or the negative experience of residents with the impact of increased tourism was not recorded. Another potential source of negative media image may be insufficient or unilaterally oriented communication of the destination society, where the importance of residents' feelings is not sufficiently clearly and credibly declared and if the benefits of tourism for the destination as a whole are not repeatedly and repeatedly communicated.

\section{Focus group interviews}

The following attitudes of respondents were identified from the group interviews conducted. The first group of questions was directed to the territory associated with the word home, which occurs in the business strategy of the destination. Most of the interviewees identified as their home places that are also commonly visited by tourists. This shows a possible link between the breadth of their perception of the word home and attitude towards tourists.

Questions about the feeling of home and well-being were focused on places associated with the positive emotions of the interviewees. Clearly the most important is for nature 
interviewed. Tábor people mention the local history, which is of supra-regional importance and as such is part of the school curriculum. On the other hand, in Sedlčany, whose history is not ascribed to such significance, the interviewees relate more to culture and art. Thence, in Sedlčany, they talk about historical monuments in connection with artistic impression. While in Tábor they perceive monuments with their entire cultural-historical context created by events and memories. Questions focused on the diversity of people, speech and traditions in the region showed that the interviewees perceived the differences little, except for minor language specificities. Two persons called Tábor festival as a local tradition, which confirms the gradual transformation of the newly introduced event into a place of memory.

The question of creating places of memory was the question: What personalities do you associate with the region? Here, the school responded as a key bearer of information. The interviewees agreed on historical figures whose knowledge was strengthened by the school. Only a few of them named personalities that were not mentioned by the school or contemporary ones.

The answers to the questions of the fourth circuit (Do you like it here; What is your heart affair?) Focused on a positive relationship with the region. The responses showed that the inhabitants of the Tábor region included a higher proportion of old-age residents to immigrants. Old people are characterized by strong local patriotism and a conciliatory attitude towards the negatives. The responses also show that the practical layout of the city and the pleasant impression of the public space, which was highly praised by the Tábor people, also have a significant impact. Respondents in Sedlčany did not share this. In both regions, the interviewees described the surrounding nature as a heart issue.

The fifth set of questions was focused on the relation of the interviewees to tourism. Both groups meet with tourists in their region and have no problem with them. Respondents do not mind the amount or behaviour of tourists. But everyone is worried about the uncontrolled increase in tourism and sees negative examples outside the region (Český Krumlov).

The sixth and final set of questions focused on knowledge of the destination organization Toulava and its intentions. It turned out that the interviewees knew the concept of Toulava, but they knew nothing more about it. He cannot describe the reasons of existence or the territory of Toulava. The only interviewee, who had more information, evaluated the offer of the destination company Toulava positively.

From the results of the Focus group interviews it can be concluded that most of the interviewed (17) perceive as part of their tourist destination part of their tourist destination, which is also part of the offer for tourists (the city they live in, or even its close surroundings). 3 respondents feel at home elsewhere but still in Toulava. And only 3 respondents perceive as their home a place that is not part of the destination offer (only their apartment).

After transferring the findings to the system of 12 attractions according to the selected methodological procedure, it can be stated that the use of semiotic analysis of the offer showed a high preference of recreational, environmental, historical and agricultural attractions on the target website and on Facebook. The same results were obtained from population research within the focus groups. The respondents also preferred environmental, historical, recreational and artistic attractiveness. Within the framework of media analysis, the most numerous were the recreational, gastronomical, and cultural-cultural attractions.

\section{Conclusions and implications}

The research showed a high level of match between the identity of residents and the identity of the destination. The findings confirmed the agreement between the results of the semiotic website analysis and the conclusions of the group interviews of residents. 
Findings from website and FB analysis confirmed compliance with the destination strategy, which defines Toulava as the landscape of heart and the landscape of home. The same findings arise from group interviews with residents. Thus, the desired match of destination identity and residency identity can be confirmed. Slight differences are apparent only in the case of content analysis of the media, from which it is possible to deduce stronger preferences of traditions. The reason is the selection of contents according to the so-called "media values". Given the exceedingly small amount of media content associated with Toulava, this difference is considered insignificant.

The high degree of product authenticity has been confirmed. The research has confirmed a low level of information (resulting in a poor awareness of residents that there is an organization making offerings from their memory locations). The use of semiotic analysis of the offer showed the overwhelming attraction of recreational, environmental, historical, and agricultural on both the destination website and Facebook. Only the order of attraction preference differs. The results of semiotic analysis agree with the results of the research of residents who also prefer environmental, historical, recreational, and artistic attractiveness.

It is possible to observe from the realized group interviews that in both examined regions nature, history and undemanding recreational sports activity are positively perceived. All activities are preferred in individual form or in small groups. Transferred into the system of tourist attractions, the interviewees accentuated environmental, historical, and recreational attractions. It can be assumed that the potential development of supply in this respect will be perceived positively by residents and some related burden will be accepted. On the other hand, products that will significantly affect the current appearance of the region will most likely not be positively accepted (adrenaline sports, large cultural events, large sports facilities, mass events, mass attractions).

Media analysis, on the other hand, showed a different order of the most popular attractions. It shows the low ability of Toulava to reach the media in order to assert itself in the content, i.e. to use so-called media and news values. The media then logically write only about current events that take place in a short time, and these are more associated with recreational, gastronomic, and traditionally cultural attractiveness. Peaceful relaxation in nature combined with views of the countryside lacks basic intelligence values. The overall media image of Toulava is relatively weak. However, it is necessary to consider the short period of existence of the Toulava destination and the fact that the assessment of individual categories is subjective. It should be done repeatedly by more people with averaging of results.

In the surveyed destination Toulava, the identity of the destination with the identity of the residents was found to be remarkably similar. This is a positive finding from the point of view of the current situation, in the context of sustainable development it is desirable to monitor the development and respond in time to any negative tendencies. The only area in which residents disagreed with the identity of the destination was the territory.

The applied research methodology enabled to obtain relevant outputs. It is not known from practice that the identity of the destination with the identity of residents is examined. Previously (always theoretically considered) investigations were not carried out due to personnel and financial demands. The three methods used in this article are less demanding in terms of capacity and cost than the quota sample research. Research can thus be carried out in destinations and repeatedly and follow time series. The Focus group method has enabled research saturation with data and yields comparable results in both categories in the same categories. The methodological approach can be recommended in general for carrying out research into identity interaction and destination management. Research data results can be compared to each other, track trends, and thus eliminate the potential risk of negative impacts resulting from growing identity mismatches. The model has proven to be functional in the destination. Practical use of the proposed three methods with appropriately set granularity (group interview method) does not generate any extreme personnel or financial costs for destinations. A possible direction of further 
research therefore appears in the field of application. It would be advisable to apply the model to other destinations as well and to repeat it over time. The application would contribute through testing to further improve the proposed methodology.

\section{Литература / References}

Abrhám, J., Wang, J. (2017). Novel trends on using ICTS in the modern tourism industry. Czech Journal of Social Sciences, Business and Economics, 6(1), 37-43. https://doi. org/10.24984/cjssbe.2017.6.1.5

Budil, I. (2013). Mýtus, jazyk a kulturní antropologie. Triton. (In Czech.)

Burns, P. M. (1999). An Introduction in Tourism and Anthropology. Psychology Press.

Burns, P. M., Novelli, M. (2006). Tourism and Social Identities: Global Frameworks and Local Realities. Elsevier.

Čajka, P., Abrhám, J. (2019) Regional Aspects of V4 Countries' Economic Development Over a Membership Period of 15 Years in the European Union. Slovak Journal of Political Sciences, 19(1), 89-105. https://doi.org/10.34135/sjps.190105

Černevičiūtè, J., Strazdas, R. (2018). Teamwork management in Creative industries: factors influencing productivity. Entrepreneurship and Sustainability Issues, 6(2), 503-516. http://doi.org/10.9770/jesi.2018.6.2(3)

Chiabai, A., Platt, S., Strielkowski, W. (2014). Eliciting users' preferences for cultural heritage and tourism-related e-services: a tale of three European cities. Tourism Economics, 20(2), 263-277. https://doi.org/10.5367/te.2013.0290

Eslami, S., Khalifah, Z., Mardani, A., Streimikiene, D. (2018). Impact of noneconomic factors on residents' support for sustainable tourism development in Langkawi Island, Malaysia. Economics and Sociology, 11(4), 181-197. https://doi.org/10.14254/ 2071-789X.2018/11-4/12

Gellner, A. (1993). Národy a nacionalismus. Nakladatelství Hř́bal. (In Czech.)

Goeldner, Ch. R., Richie,J. R. (2014). Cestovníruch. Principy, príklady, trendy. BizBooks. (In Czech.)

Herget, J., Petrů, Z., Abrhám, J. (2015). City branding and its economic impacts on tourism. Economics and Sociology, 8(1), 119-126. https://doi.org/10.14254/2071789X.2015/8-1/9

Horáková, H. (2007). Národ, kultura a etnicita v postapartheidní Jižní Africe. Gaudeamus. (In Czech.)

Horáková, H., Fialová, D. (2014). Transformace venkova: Turismus jako forma rozvoje. Aleš Čeněk Press. (In Czech.)

Huimin, G., Ryan, Ch. (2011). Tourism destination evolution: a comparative study of Shi Cha Hai Beijing Hutong businesses' and residents' attitudes. Journal of Sustainable Tourism, 20 (1). https://doi.org/10.1080/09669582.2011.610511

Huntington, S. (2001). Stret civilizací, boj kultur a proměna světového rádu. Tybka Publishers. (In Czech.)

Jandourek, J. (2001). Sociologický slovník. Portál. (In Czech.)

Koilo, V., Ryabushka, L., Kubakh, T., Halik, J. (2020). Assessment of government debt security of emerging markets: theory and practice. Investment Management and Financial Innovations, 17(1), 35-48. https://doi.org/10.21511/imfi.17(1).2020.04

Linhart, J., Petrusek, M., Vodáková, A., Maříková, H. (1996). Velký sociologický slovník. Karolinum. (In Czech.)

Lisin, E., Shuvalova, D., Volkova, I., Strielkowski, W. (2018). Sustainable development of regional power systems and the consumption of electric energy. Sustainability, 10(4), 1111. https://doi.org/10.3390/su10041111 
Maitah, M., Kuzmenko, E., Smutka, L. (2016). Real effective exchange rate of rouble and competitiveness of Russian agrarian producers. Economies, 4(3), 12. https://doi. org/10.3390/economies4030012

McCannell, D. (2011). The Ethic of Sight-Seeing. University of California Press.

Naglova, Z., Boberova, B., Horakova, T., Smutka, L. (2017). Statistical analysis of factors influencing the results of enterprises in dairy industry. Agricultural Economics-Zemedelska Ekonomika, 63(6), 259-270. https://doi.org/10.17221/353/2015-AGRICECON

Oh, H., Fiore, A. M., Jeoung, M. (2007). Measuring experience economy concepts: Tourism applications. Journal of Travel Research, 46(2), 119-132. https://doi. org/10.1177/0047287507304039

Paasi, A. (1986). The institutionalization of regions: a theoretical framework for understanding the emergence of regions and the constitution of regional identity. Fennia, 164(1). https://fennia.journal.fi/article/view/9052

Palatková, M. (2011). Marketingový management destinací. Grada. (In Czech.)

Pavolová, H., Bakalár, T., Emhemed, E. M. A., Hajduová, Z., Pafčo, M. (2019). Model of sustainable regional development with implementation of brownfield areas. Entrepreneurship and Sustainability Issues, 6(3), 1088-1100. http://doi.org/10.9770/jesi.2019.6.3(2)

Peeters, P., Higham, J., Cohen, S., Eijgelaar, E., Gössling, S. (2019). Desirable tourism transport futures. Journal of Sustainable Tourism, 27(2), 173-188. https://doi.org/10.1080 /09669582.2018.1477785

Radovic, D., Strielkowski, W., Wang, J., Cepel, M., Rausser, G. (2017) Economic analysis of sustainable tourism: a case study of Nottingham. Transformations in Business \& Economics, 16(2B), 703-714.

Richards, G. (2007). Cultural Tourism, Global and Local Perspectives. Atlas.

Rýsová, L., Dobrýk, M. (2013). Regional development - basic theoretical approaches. Politické Vedy 16 (2). http://www.politickevedy.fpvmv.umb.sk/userfiles/file/2_2013/ RYSOVA_DOBRIK.pdf. (In Czech.)

Šauer, M., Vystoupil, J., Holešínská, A. (2015). Cestovní ruch. Masarykova univerzita Press. (In Czech.)

Shevyakova, A., Munsh, E., Arystan, M. (2019). Information support for the development of tourism for the diversification of the economy of Kazakhstan. Insights into Regional Development, 1(2), 138-154. https://doi.org/10.9770/ird.2019.1.2(4)

Strielkowski, W., Čábelková, I. (2015). Religion, culture, and tax evasion: Evidence from the Czech Republic. Religions, 6(2), 657-669. https://doi.org/10.3390/rel6020657

Svobodová, M. (2016). On the Concept of Legislative Acts in the European Union Law. The Lawyer Quarterly, 6(1). https://tlq.ilaw.cas.cz/index.php/tlq/article/view/209/0

Van der Schyff, T., Meyer, D., Ferreira, L. (2019). An analysis of impact of the tourism sector as a viable response to South Africa's growth and development challenges. Journal of International Studies, 12(1), 168-183. https://doi.org/10.14254/2071-8330.2019/12-1/11

Vasylchak, S., Halachenko, A. (2016). Theoretical basis for the development of resort services: regional aspect. International Economics Letters, 5(2), 54-62. https://doi. org/10.24984/iel.2016.5.2.3

Xue, L., Kerstetter, D., Hunt, C. (2017). Tourism development and changing rural identity in China. Annals of Tourism Research, 66, 170-182. https://doi.org/10.1016/j.annals.2017.07.016

Zelenka, J., Pásková, M. (2012). Výkladový slovník cestovního ruchu. Praha: Linde. (In Czech.)

Zhang, C., Xiao, H. (2014). Destination development in China: towards an effective model of explanation. Journal of Sustainable Tourism, 22(2), 214-233. https://doi.org/10.10 80/09669582.2013.839692 